\title{
PERLINDUNGAN HUKUM ANAK BERDASARKAN SYARI'AH DAN HUKUM POSITIF
}

\author{
Bahtiar \\ STIH Cokroaminoto Pinrang
}

\begin{abstract}
ABSTRAK
Anak adalah manusia yang belum dewasa karena ia belum dewasa, seorang anak masih membutuhkan perlindungan dari orang dewasa (orang tua, keluarga, masyarakat dan pemerintah). Pertama tujuan penelitian adalah untuk perlindungan yang diberikan oleh orang dewasa di Indonesia belum optimal sehingga anak belum sepenuhnya diberikan oleh orang tua, masyarakat dan pemerintah. Kedua ruang lingkup penulisan Seringkali anak diposisikan sebagai objek kehidupannya sendiri, sehingga ia tidak dapat menikmati hal-hal yang dapat menjadi hak baginya dan bahkan sampai dengan upaya tindak kekerasan terhadap anak kerapkali terjadi. Data base dari Komnas Perlindungan Anak (Komnas PA) menunjukkan peningkatan kekerasan mental, spiritual, fisik, hingga masalah social yang terjadi terhadap anak. Ketiga metode yang digunakan adalah menggunakan analisis yuridis bermotif berdasar data sekunder, juga Al-Qur'an dan Hadist. Keempat ruang lingkup penelitian sesungguhnya ada banyak factor yang menyebabkan ketidak mengertian oarng tua dan tindak kekerasan yang terjadi, antara lain tidak maksimalnya peran dan fungsi orang tua, factor kemiskinan, tekanan hidup semakin meningkat, dan keramahan terhadap pasangan. Namun yang sangat disayangkan perhatian pemerintah pun masih minim terlihat dengan undang-undang perlindungan anak yang terhitung baru dan implementasinya masih tersendat di lapangan. Untuk itulah diperlukan kerja sama yang sinergis antara orang tua, keluarga, masyarakat dan pemerintah dalam menciptakan dan mencerdaskan anak Indonesia melalui pendekatan agama dan pendekatan yuridis formal. Kelima kesimpulan anak sesungguhnya amanah dari Allah. Karena amanah, berarti orang tua yang dititipi tersebut harus menjaga amanah tersebut dengan sebaik-baiknya. Selain sebagai bagian dari maasyarakat, orang tua berhak pula meminta kepada pemerintah untuk lebih memperhatikan hak anak sesuai dengan kebutuhan psikologi perkembangan kejiwaannya. Oleh karena itu perlindungaan hukum anak oleh suatu Negara mutlak adanya menuju realisasi perlindungan anak yang spiritual-positif.
\end{abstract}

Kata Kunci : perlindungan hukum, hak anak

\section{A. PENDAhuluan}

Berbicara tentang perlindungan hukum anak, secara otomatis hal tersebut merupakan tanggung jawab kita bersama, sehingga sudah tentu memerlukan sebuah upaya tidak hanya individual, akan tetapi juga secara kolektif dari kita semua untuk ikut berperan, serta terlibat aktif dalam rangka memberikan perlindungan bagi anak.

Karena sesungguhnya anak adalah amanah dan karunia dari Allah SWT - Walladzina hum li amanatihim wa 'ahdihim Raa'un ( Al Qur'an- al Karim , Surat Al-Mu'minun ayat 8), pada dirinya melekat harkat dan martabat sebagai manusia seutuhnya. Anak memiliki peran strategis dan mempunyai ciri dan sifat khusus yang menjamin kelangsungan eksistensi agama, bangsa dan Negara di masa depan karena anak adalah tunas, potensi, dan generasi muda serta penerus cita-cita perjuangan agama dan bangsa.

Namun akhir-akhir ini seringkali munculdalam pelbagai pemberitaan baik itu melalui media mapun elektronik adalah 
telah terjadi beragam bentuk penyimpangan terhadap anak, dengan argumentasi melindungi anak-anak padahal dalam realitasnya adalah terjadinya viktimisasi (kekerasan) mental, spiritual, fisik, hingga masala social. Oleh karena itu, guna mencegah atau setidaknya mengurangi halhal yang demikian adanya, diperlukan sebuah terobosan formula pomahaman yang komprehensif mengenai hak anak dan perlindungan bagi anak mereka. Di samping itu juga perlunya pemahaman yang integral mengenai pedoman dan dasar syari'i dan hukum positif dalam rangka merealisasikan perlindungan hak anak. Karena anak merupakan generasi penerus bangsa yang sudah tentu memiliki hak dan kewajiban untuk ikut serta dalam dalam membangun agama dan bangsa, sehingga terwujud Negara Indonesia Raya yang maju, sejahtera dan aman.-Baldatun Thayyibatun Wa Rabbun Ghafur-(Al Qur'an-al Karim, Surat as Saba ayat 15).

Oleh karena itu anak Indonesia yang merupakan bagian dari manusia Indonesia yang harus diasuh, dibesarkan dan diarahkan sebagai manusia seutuhnya dan berimbang, sehingga mempunyai kapasitas serta kapabilitas untuk melaksanakan hak dan kewajiban sebagai bagian dari umat dan warga Negara yang penuh tanggung jawab, bermanfaat dan bermartabat sesuai dengan ajaran Islam. Pancasila dan Undang-undang Dasar 1945. Adapun hak dan kewajiban anak, terdapat dalam pelbagai bidang penghidupan dan kehidupan keluarga, masyarakat dan Negara, yang semestinya yang menjadi kewajiban bersama secara simultan mengupayakan terciptanya perlindungan anak, dengan harapan agar anak dapat merealisasikan segala kepentingannya secara optimal.

Dalam rangka terciptanya realisasi perlindungan anak yang spiritualpositif, dapat dipertanggungjawabkan serta bermanfaat, maka diperlukan pemahaman mengenai pendidikan anak dalam kerangka islami dan penyempurnaan dari realisasi peraturan perundang-undangan yang telah ada dan diberlakukan secara optimal.

Tujuan penulisan ini adalah :

1. Mengetahui hak anak menurut agama Islam

2. Mengetahui hak anak menurut hukum positif Indonesia

3. Proses implementasi perlindungan anak di Indonesia

4. Mencari akar masalah yang menyebabkan terjadinya tindak kekerasan terhadap anak dan solusinya.

\section{B. PEMBAHASAN}

\section{Pendidikan Anak Berdasarkan Syari'ah Dan Perlindungan Hukumnya}

Anak adalah amanah dan karunia dari Allah SWT - Walladzina hum li amanatihim wa 'ahdihim Raa'un ( $\mathrm{Al}$ Qur'an- al Karim , Surat al Mu'minun ayat 8), pada dirinya melekat harkat dan martabat sebagai manusia seutuhnya. Anak memiliki peran strategis dan mempunyai ciri dan sifat khusus yang menjamin kelangsungan eksistensi bagsa dan Negara di masa depan karena anak adalah tunas, potensi, dan generasi muda serta penerus cita-cita perjuangan agama dan bangsa.

Oleh karena itu, merupakan sebuah tanggung jawab besar untuk mendidik anak. Islam sangat memperhatikan proses pendidikan yang berlangsung dalam membentuk anak menjadi anak yang sholeh dan sholeha. Mengingat tujuan pendidikan dalam Islam adalah menciptakan individu untuk dapat beribadah kepada Allah SWT. Pengertian ibadah di sini pun merupakan pengertian secara totalitas yang tidak membatasi ibadah pada shalat, puasa dan haji, melainkan setiap karya yang dilakukan seorang muslim dengan niat beribadah kepada Allah. Begitu pula dalam hal mendidik anak. (Aisyah Abdurrahman al Jalal, al Mu'atstsirat as Salbiyah fi Tarbiyati at Thifli Muslim wa Taruq 'Ilajiha, h. 76)

Di dalam Islam, anak adalah nikmat Allah yang merupakan amanah bagi orang tuanya dan mereka akan dimintai 
pertanggungjawaban di akherat kelak. Apakah anak yang dititipkan kepada mereka dijaganya atau diterlantarkannya. Melihat besarnya tanggung jawab orang tua dalam mendidik anak tersebut, maka Islam sudah memberikan tuntutan dan pedoman mengenai bagaimana menjadi orang tua yang baik dalam memberikan hak dan pelayanan kepada anak-anaknyav sejak proses pencarian calon pasangan, kemudian menunggu proses persalinan dan membersarkan anak dengan pendekatan psikologi perkembangan jiwa sang anak yang Islami.

Al Qur'an dan al Hadits memberikan serangkaian proses yang panjang dalam mempersiapkan pendidikan sang anak mulai dari pencarian calon orang tua dengan memperjelas asal usulnya (siapakah orang tuanya, agamanya, kecantikannya, kekayaannya) dan diatara berbagai macam bentuk asal muasal tersebut, islam memberikan kecendongan terhadap calon pasangan yang pemahaman agamanya baik dan benar.

\section{Perlindungan Hukum Anak Berdasarkan Hukum Positif Landasan Yuridis}

Lalu bagaimana pandangan anak dari sudut hukum positif?. Terkait dengan kondisi demikian, perlindungan anak merupakan suatu usaha bersama dalam melindungi anak untuk melaksanakan hak dan kewajibannya secara positif, di mana perlindungan anak tersebut merupakan suatu hasil interaksi antara pihak tertentu yang terdiri dari orang tua, keluarga, masyarakat, pemerintah dan Negara yang berimplikasi bagi tindakan hukum (yuridis) dan mempunyai akibat hukum yang harus diselesaikan dengan berpedoman serta berdasarkan hukum. Karena bagaimanapun juga, tidak ada satu pun institusi kemasyarakatan yang berdiri sendiri, termasuk institusi hukum (Soerjono Soekanto, 1997, 3-11). Untuk itu Undangundang Perlindungan Anak (UUPA) adalaah langkah kongkrik terhadap pengaturan berdasarkan hukum, demi menindak serta mencegah pelaksanaan perlindungan anak yang menimbulkan penderitaan mental, fisik dan social pada anak yang bersangkutan.

Indonesia adalah Negara hukum.

Begitu pula dalam permasalahan perlindungan anak, dasar hukum dalam memperlakukan anak di Indonesia (Anton Charliyan, 2006) adalah sebagai berikut :

a. UU No. 6 tahun 1974 tentang Ketentuan Pokok Kesejahteraan Sosial

b. UU No. 6 tahun 1979 tentang Kesejahteraan Anak

c. UU No. 23 tahun 1992 tentang Kesehatan

d. UU No. 3 tahun 1997 tentang Pengadilan Anak

e. UU No. 39 tahun 1999 tentang Hak Azasi Manusia (HAM)

f. UU No. 1 tahun 2000 tentang Pengesahan ILO-Konvensi ILO No. 182 tentang Pelanggaran dan Tindakan Segala Penghapusan Bentuk-bentuk Kerja Terburuk Anak)

g. UU No. 2 tahun 2002 tentang Kepolisian RI

h. UU No. 23 tahun 2002

i. UU No. 23 tahun 2002 tentang Pelindungan Anak sudah disahkan selama lima tentang Perlindungan Anak

j. KAPRES RI No. 36 tahun 1990 tentang Pengesahan Konvensi Hak Anak

k. SKB 3 Menteri dan KAPOLRI tahun 2002 tentang PPT terhadap Perempuan dan Anak Korban Kesejahteraan Sebagai leadingnya

Undangtahun, tetapi pelaksanaan di lapangan belum berjalan seperti yang di harapkan. Masing-masing pihak yang terlibat dalam pelaksanaan undang-undang itu menyampaikan sederet persoalan yang secara nyata mereka hadapi sehari-hari di lapangan dalam pelaksanaan undangundang tersebut.

Undang-undang Perlindungana Anak tersebut diadakan dengan tujuan menjamin terpenuhinya hak-hak anak agar dapat hidup, tumbuh, berkembang, dan 
berpartisipasi optimal sesuai harkat dan martabat kemanusiaan, mendapat perlindungan dari kekerasan dan diskriminasi. Kebebasan untuk beribadah sesuai agamanya, perlindungan jaminan kesehatan, dan hak mendapat pendidikan adalah sebagian isi dari Undang-Undang Perlindungan Anak. Sementara perlindungan yang sifatnya khusus diberikan anatara lain untuk anak dalam situasi darurat, anak yang berdahadapan dengan hukum, anak dari kelompok minoritas dan terisolasi, anak yang tereksploitasi secara ekonomi-seksual, anak yang diperdagangkan, anak korban peran fisik-mental, anak cacat, serta anak korban perlakuaan salah dan penelantaraan, yang diatur dalam Pasal 59 Undang-Undang No. 23 Tahun 2002 tentang Perlindungan Anak.

Salah satu alasan mengapa Undang-Undang Perlindungan Anak harus lahir dan harus dilaksanakan adalah karena undang-undang ini memberikan perlindungan yang lebih baik dibandingkan dengan KUPH. Misalnya, ada sanksi cukup tinggi berupa hukuman penjara maksimal 3 tahun dengan denda maksimal Rp. 300 juta dan minimal 60 juta terhadap tindakan berhubungan dengan pemerkosaan dan pencabulan terhadap anak (Ratna Batara Munti, 2004).

Namun dalam realitanya tampak bahwa di lapangan, pelaksanaan Undangundang ini masih jauh dari memuaskan. Hal itu dapat dilihat dalam beberapa kasus, misalnya pada kasus, misalnya kasus terhadap anak perempuan korban kekerasan, dimana diperlukan korban kekerasan, di mana diperlukan adanya terebosan dari kepolisian, misalnya dalam soal visum sebagai bukti telah terjadi kekerasan seksual, juga proses di kejaksaan dan di pengadilan.

Oleh karena di atara aparat masih belum terdapat kesamaan persepsi dalam melindungi anak, maka sangat mungkin terjadi perbedaan antara jaksa dan hakim dalam menetapkan hukuman bagi terdakwa. Contoh kasus ialah apa yang dilakukan oleh Lembaga Bantuan Hukum
Asosiasi Perempuan Indonesia untuk Kesadilan (LBH APIK) yang pernah melakukan pendampingan bagi korban perkosaan terhadap anak perempuan dimana jaksa menuntut hukuman satu tahun, namun hakim akhirnya member putusan tujuh tahun penjara bagi pelaku (Ratna Batara Munti, 2004).

adalah $\begin{gathered}\text { Persoalan mendasar disini } \\ \text { meskipun }\end{gathered}$ Perlindungan Anak sudah berlaku selama lima tahun, tetapi kekerasan terhadap anak tindak menyurut, bahkan kekerasan terhadap anak perempuan pun, -terutama kekerasan seksual-terus menghiasi media massa kita.

Entah karena ketidaksertiusan atau karena keengganan para penegak hukum sehingga masih saja mereka tidak mau menggunakan Undang-Undang Perlindungan Anak dan lebih memilih kitab undang-undang hukum pidana, contoh lainnya adalah sebelum sungguhsungguhnya pelaksanaan aturan perundangan yang melindungi anak dan perempuan adalah belum dimasukkannya ruang pelayanan khusus (RPK) kedalam struktur kepolisian sehingga mengakibatkan tidak banyak polwan yang berugas di RPK yang merupakan ujung tombak pelayanan terhadap perempuan dan anak korban kekerasan. Data dari MABES polri menyebutkan bahwa RPK berjumlah 237 buah yang tersebar di seluruh Indonesia. Ruang RPK yang digunakan pun baru sebatas menggunakan rumah sakit polri yang ada di Indonesia (Charlyan, 2006).

Ruang pelayanan ini dilayanani oleh polwan dan dibuat terpisah dari ruang dari pelayanan lainnya dengan tujuan untuk memberi ruang bagi korban membuka persoalan tanpa harus merasa dipermalukan bila penerimaan laporan adalah polisi lakilaki. Karena tidak di dalam struktur, maka anggaran untuk RPK pun tidak memadai. Akibatnya, tidak jarang seorang polwan harus mengeluarkan uang pribadi untuk membantu pelapor yang tidak memiliki uang. Misalnya, untuk membuat visum kerumah sakit bagi korban pemerkosaan. 
Karena korban tidak memiliki uang, maka polwan berinisiatif menggunakan uang pribadinya untuk membawa korban kerumah sakit (Murnila, SH, 2004).

Minimnya RPK yang hanya terbatas pada Rumah Sakit Polri tidak mapu menampung jumlah korban. Semua kenyataan ini membuktikan ketidakseriusan dan ketidakpedulian pemerintah melaksanakan amanah Undangp-Undang. Hal ini berdampak pula di dalam kebijakan anggaran Negara. Di sisi lain, ketidakpedulian pemerintah itu tidak tercermin dari munculnya dugaan penyalagunaan dana untuk Komisi Perlindungan Anak Indonesia (KPAI) oleh pejabat di Kantor Menteri Negara Pemberdayaan Perempuan (Meneg PP). Hal tersebut masi teringat dalam benak kita dimana rapat kerja antara Meneg PP dan Komisi VIII DPR, pada beberapa tahun lalu, ketika ada anggota legislatif yang mempertanyakan dugaan penyalagunaan dua pertiga dari total Rp. 909 juta dana yang disediakan Departemen Keuangan untuk pembentukan struktur KPAI (www.kompas.co.id).

Di samping itu juga, masalah utama penegakan hukum termasuk hukum perlindungan anak di negeri kita, sejatinya bukan terletak pada aturan main, akan tetapi terletak pada hilangnya etika, membuat hampir semua proyek repormasi hukum dibajak mafia peradilan, padahal perbaikan etika seharusnya dapat dimulai dari Mahkamah Agung (MA) dengan mengangkat hakim Agung yang integritasnya jelas, jika etika di MA terjaga maka suap di pengadilan tidak berarti (Kompas 11 Januari 2007).

Menghadapi kondisi tersebut, tidak bias tidak, masyarakat kita harus membangun jaringan dan bekerja di semua lini, dari tingkat kebijakan hingga ke akar rumput, serta perlunya upaya bagi para jaksa tentunya, untuk mengikuti pendalaman materi semisal dengan diadakannya penataran atau berupa semacam-diklat, agar supaya mereka menggunakan Undang-Undang No. 23
Tahun 2002, sehingga bias menjerat pelaku dengan hukuman seberat-beratnya, dan Undang-Undang ini diharapkan dapat disosialisasikan di tingkat RT (rukun tetangga) karena masyarakat, seringkali RT menjadi rujukan terdekat dalam hal struktur kepemerintahan pada tingkat mikro.

\section{Akar Masalah Kekerasan Terhadap Anak Di Indonesia}

Untuk menjawab itu kita harus melihat dari perspektif budaya. Seringkali anak tidak dilihat sebagai subjek. Seringkali anak tidak dilihat sebagai subjek, melainkan objek. Karena anak merupakan objek, maka anak dilihat sebagai hak milik orang dewasa. Oleh para orang tua, anak juga dianggap sebagai asset karena hubungan ini bersifat kepemilikan maka si empunya memiliki oteritas atas apa yang ingin dilakukan terhadap sang anak. Inilah yang menjadi akar pengabaian atas pemenuhan hak anak. Seorang anak pada dasarnya memiliki banyak ketergantungan terhadap orang dewasa. Ketergantungan inilah yang secara sadar atau tidak sadar mendorong orang dewasa melakukan pengabaian terhadap hak-hak anak tersebut.

Padahal seorang anak seharusnya dipandang sebagai seorang manusia yang mempunyai hak layaknya seperti manusia yang lain. Sedangkan dalam Islam, anak dianggap sebagai titipan Allah dan harus diperlakukan dengan baik. Anak memiliki hak yang melekat pada dirinya yang wajib diberikan. Namun banyak orang yang tidak mengerti bentuk dari hak-hak tersebut. Jadi cara pandang anak sebagai hak milik dan makhluk kecil yang tidak mempunyai hak adalah pemicu kekerasan terhadap anak (Gosita, 1985:88).

Di samping itu, pemahaman keagamaan para orang tua dan orang dewasa masih sangat minim terhadap pemenuhan pelayanan hak dasar anak. Kerap kali dijumpai, perlakuan keras dan menyimpang secara psikologis yang diterapkan dalam mendidik anak, Terlebih pada usia emas yakni usia pra sekolah. Para ahli psikologis dan ahli pendidikan sepakat 
bahwa merupakan hak anak mendapat perhatian utuh dan baik di masa emasnya. Dr. Kanner dalam bukunya Child Psychatry memuat hasil penelitian terhadap sejumlah anak yang mengalami kesulitan dalam belajarnya dan di sekolah dan juga mendapat kesulitan di dalam pergaulan. Ia memaparkan bahwa setiap kasus yang terjadi bermula dari sikap dan tindak tanduk orang tua di rumah.

Para ahli psikologi anak lain pun berpendapat senada dengan Dr. Kenner sehingga pernyataan yang dikemukakan oleh Dorothy menjadi semakin kuat. "Apalagi anak dibesarkan dalam keadaan tekanan, ia akan belajar tidak menghargai orang lain".

Bahkan Iman Ibnu Qayyim al Jauziyah telah menyatakan bahwa: "Barang siapa yang melalaikan pendidikan anaknya, yakni dengan tidak mengajarkan hal-hal yang bermanfaat, membiarkan mereka terlantar, maka sungguh dia telah berbuat buruk. Mayoritas anak melakukan kesalahan karena orang tuanya yang tidak mempersiapkan dengan matang pendidikan yang baik bagi anaknya dan tidak mengarjakan mereka kewajiban agama dan sunnahnya, mereka menelantarkan anak sejak kecil, sehingga mereka tidak dapat memberikan manfaat kepada diri sendiri, orang tua, agama, dan bahkan bangsanya. Di Indonesia ini sudah ada perangkat hukum yang melindungi anak seperti UU No. 6 tahun 1974 tentang Ketentuan Pokok Kesejahteraan Sosial, UU No. 4 tahun 1979 tentang Kesejahteraan Anak, UU No. 23 tahun 1992 tentang kesekatan, UU No. 3 tahun 1997 tentang Pengadilan Anak, UU No. 39 tahun 1999 tentang Hak Azasi Manusia (HAM), UU No. 1 tahun 2000 tentang Pengesahan ILO-Konvensi ILO No. 182 tentang Pelanggaran dan Tindakan Segala Penghapusan Bentuk-bentuk Kerja Terburuk Anak), UU No. 2 tahun 2002 tentang Kepolisian RI, UU No. 23 tahun 2002, UU No. 23 tahun 2002 tentang Pelindungan Anak sudah disahkan selama lima tentang Perlindungan Anak, KAPRES RI No. 36 tahun 1990 tentang Pengesahan
Konvensi Hak Anak, SKB 3 Menteri dan KAPOLRI tahun 2002 tentang PPT terhadap Perempuan dan Anak Korban Kesejahteraan. Namun dalam implementasinya perangkat-perangkat hukum ini tidak cukup efektif, melihat jumlah kekerasan terhadap anak secara statistic justru naik secara signifikan.

Terdapat sejumlah mitos yang dianggap menjanggal upaya perbaikan nasib anak Indonesia. Mitos-mitos ini menyebabkan orang dewasa gagal memprsepsi anak sebagai manusia, dan memperlakukan anak hanya sebagai obyek dalam keluarga, masyarakat, maupun Negara (Kompas, 2003). Bahkan berbagai lembaga dan legislasi nasional yang dibuat untuk melindungi hak anak pun ditengarai masih berprilaku serupa. Bagaimana ini bias terjadi? Harus dipahami, perjuangan hak anak tumbuh seiring pengakuan terhadap nilai-nilai humanisme universal. Hak asasi anak merupakan bagian dari hak asasi manusia. Upaya perlindungan anak asasi manusia. Upaya perlindungan anak diberikan dalam kesadaran, anak belum punya kapasitas legal untuk melakukan sesuatu yang berimplikasi hak anak, tanggung jawab pelaksanaannya diserahkan kepada orang tua dan masyarakat (Gosita, 1985: 79).

Namun, filsafat humanisme yang dibawah system kapasitas modern yang kita anut kini mendorong tumbuhnya nilai-nilai kemanusiaan yang memihak kebebasan individual dan mempreoritaskan kebutuhan individu di atas relasi sosial. Negera telah memeinkan peran utama dalam reproduksi kapitalisme dan pembentukan lingkungan perkotaan (Chris Barket, 2003:312). Dalam praktiknya, nilainilai humanistic sering menyerah pada dorongan kebutuhan individual yang menghasilkan keuntungan lebih besar. Individualitas juga merasuk dalam kesadaran manusia dan mendominasi struktur relasi antar manusia, hingga mampu menggeser nilai-nilai luhur dalam relasi orang tua dan anak. Globalisasi yang dimotivasi kapitalisme memaksa menusia 
untuk kreatif mengkapitalisasi apa pun demi mendapat laba. Tentu saja anak, dalam posisinya yang lemah secara fisik, sosial, maupun hukum, menjadi pilihan yang amat atraktif untuk dikapitalkan.

Kondisi ini diperkeruh apresiasi budaya atau pemahaman agaman yang sempit, di mana ia mengerjakan hubungan orang tua-anak dalam relasi subordinat, di mana orangtua adalah pihak yang bertanggung jawab untuk membesarkan dan memenuhi kebutuhan anak. Orangtua lalu merasa berhak melakukan apa pun terhadap anaknya melalui berbagai dari agama dan budaya, termasuk prinsip, "demi kebaikan anak". Orang tua juga sering sulit melepas identifikasi dirinya dalam diri anak. Anak dianggap mengemban aneka obsesi dan harapan yang ingin ia capai. Akibatnya, konsep "demi kebaikan anak" sering menjelma menjadi "demi kebaikan orangtua".

Meminjam Istilahnya CAROL Bellam Direktur Eksekutif UNICEF untuk Asia-Pasifik, dalam pidato pembukaan pertemuan Konsultasi Tingkat Menteri se Asia Timur dan Pasifik tentang Anak awal Mei lalu bahwa "..... Semua berawal daari satu hal, investasi pada anak-anak". Ungkapan "investasi pada anak-anak" harus dibaca hati-hati, mengingat istilah investasi sangat berbau ekonomi. Pertimbangan utama dalam investasi adalah keuntungan insvektor. Investasinya jelas diperlukan sebaik mungkin, namun tujuan akhir tetap kepentingan insvektor. Bila logika ini terus digunakan, pemaknaan eksploitatif inilah yang masuk ke bawah sadar manusia dan mengendalikan perilaku tanpa kita sadari.

Pada kenyataannya, manusia sering memperlakukan anak sebagai properti, simbol prestise, atau atribut standar dari satatusnya sebagai manusia dewasa. Misalnya, dengan menjadikan anak sebagai alasan untuk menikah atau mempertahankan perkawinan. Padahal, anak punya hak untuk tumbuh dalam rumah tangga yang sehat sejahtera secara psikologis. Hak ini sering terlanggar saat istilah "kepentinganterbaik untuk anak" ditafsirkan secara egois demi kepentingan (calon) orang tuanya. Sudah waktunya unsuk hak anak masuk dalam persyaratan perkawinan, terutama bagi pasangan yang berminat punya anak. Mereka harus paham, mampu, dan besedia memenuhi hak anak agar anak tak lagi jadi aset atau dekor rumah tangga berkala.

Rapuhnya perlindungana anak di Indonesia juga disebabkan selama ini isu anak diperlakukan bagai burung dalam sangkar. Orang tua tertarik berparsitipasi karena "anak" adalah isu yang eksotik, segala dukungan fasilitas dan dana relative mudah diperoleh karena manusia mudah tersentuh perasaannya bila menyangkut urusan anak. Selain itu, isu anak dianggap soft issue karena lebih bermuatan sosial atau amal, dan relative apolitis. Padahal, kegiatan posisi bargaining amat siknifikan bagi keberhasilan gerakan perlindungan anak. Lembaganya dukungan politik membuat gerakan ini dimanfaatkan sebagai fungsi sublimasi dari aneka kepentingan selain kepentingan anak, misalnya, pengumpulan simpati politik, popularitas, promosi jabatan, uang, atau surge ( Gosita: 109 ).

Pertanyaannya kini, apa yang membuat masalah anak menjadi signifikan hingga butuh banyak perhatian, mulai dari budaya, agama, pendidikan sampai politik? Jawabnya, karena penyelesaian separuh hati atau sekedar seremonial justru membahayakan perkembangan emosi dan struktur kepribadian anak. Artinya, cita-cita perbaikan nasif anak bakal makin jauh melayang ketika fungsi-fungsi perlindungan anak gagal dilaksanakan orang tua atau masyarakat, peran Negara kembali penting.

Salah satu isi Undang-undang Perlindungan Anak No. 23 tahun 2002 adalah pembentukan Komisi Perlindungan Anaka INdonesi (KPAI). Lembaga ini diharapkan berperan seprti Komnas HAM, dengan konsentrasi pada masalah anak. Di luar beberapa kelemahan materiil dari konsep KPAI, lembaga ini perlu didukung, setidaknya atas dua alasan. Pertama, untuk menjamin Negara dan perangkatnya 
menjalankan fungsi perlindung ha kanaka sebagaimana tertuang dalam UU dengan serius dan bertanggung jawab. Kedua, guna memastikan isu anak tidak dimarjinalisasi sebagai pekerjaan departemen sosial atau pemberdayaan perempuan, tetapi juga menjadi agenda wajib tiap institusi pengambilan kebijakan. Misalnya, dengan membuat analisis dan pernyataan tentang pengaruh suatu kebijakan terhadap anak (child impact statement), yang kemudian dioperasionalkan dalam anggaran. Begitu pula dengan Depertemen Agama yang memiliki tugas dan tanggung jawab dalam perihal pelaksanaan ibadah. Depertemen ini sudah ada pendidikan bagi pasaangan calon pengantin (pendidikan pra nikah) namun implementasi di lapangannya seringkali pendidikan pra nikah tersebut hanya menjadi ritual pormalitas dan tidak bermanfaaat bagi persiapan pernikahan yang sakinah. Sehingga banyak pasaangan orang tua yang belum mengerti bagaimana mempersiapkan proses pendidikan yang baik bagi anak-anak mereka. Walaupun secara umum, pendidikan buat anak-anak baru dimasukkan kedalam pengelolaan TK/TPA atau BKPRMI buat para remaja Islamnya. Lagi pula depertemen ini belum ada direktorat khusus yang menangani anak-anak, sedangkan Pendidikan nasional yang sudah lebih dahulu dengan pendidikan anak usia dini (PAUD) pun belum maksimal memberikan masa masa depan yang lebih baik bagi anak Indonesia. Wacana PAUD baru terbentur pada keterbatasan pemahaman pendidikan pra sekolah dan belum pada pembentukan dan tumbuh kembang anak secara integral. Di samping itu, sosialisai hak dan perlindungan anak dari pemerintah masih sangat minim.

Fenomena di atas menunjukkan perhatian pemerintah dalam perlindungan dan penegakan hukum anak baik dari sudut syari'ah(Depertemen Agama) dan hukum positifnya belum maksimal. Membuat keniscayaan jikalau sisten tersebut tidak direvisi maka angka kekerasan pada anak semakin bertambah. Dana pada beberapa tahun belakangan meningkatnya tidak menggambarkan tindak kekerasan terhadap anak merupakan phenomena snow baall. Kasus yang terjadi tidak menggambarkan angka yang sesungguhnya bahkan sangat mungkin kejadian yang sebenarnya jauh lebih besar dari yang terdata.

Kriteria keseriusan Negara dalam melindungi hak anak akan terlihat dari beberapa jauh analisis ini dijadikan preoritas pertimbangan dalam pengambilan kebijakan. KPAI juga harus mendorong keterlibatan anak dalam berbagai kebijakan atau pengambilan keputusan yang menyangkut nasibnya. Penguatan parsitipasi anak tidak hanya untuk merangsang sentivitas sosial dan kemampuan toleransi, tetapi juga melatih anak bertanggung jawab atas keputusan yang diambil bersama.

Ini bukan konsep khayalan. Tahun 1996, di Lebanon, sxejumlah anak yang berusia 16-18 tahun berparsitipasi dalam sidang perlamen yang membahas masalah anak, sepeti pendidikan dan kesehatan. Hasilnya positif, karena sejak itu maslah anak menjadi isu politik serius di Lebanon. Hal ini tentunya sejalan dengan prinsip dasar hak anak yang juga termuat dalam UU No. 23 tahun 2002, yaitu penghargaan terhadap parsitipasi anak. Perlamen Anak, sedikitnya merupakan langkah awal. Mungkin suatu saat, pendapat anak dalam berbagai isu, seperti RUU Sisdiknas atau Panja Sukhoi, bias diperhitungkan, mengingat baik Depdiknas maupun Bulog adalah institusi yang amat relavan denga kesejahteraan mereka. Di Indonesia, penetapan total hak anak masih jauh dari sempurna, namun langkahke sana harus diambil. Bagaimanapun anak tidaak bertanggung jawaab atas perilaku kita. Sebaliknya, mereka dipastikaan mewarisi masalah akibat perbuatan kita saan ini. Seperti yang dinyatakan White Lion dalam lagu Where The Children Cry .... whan have we become..Just look what we have done... all that we destroyed... you must build again..

\section{Mengabaikan Hukum Anak}


Fenomena mengenai hak anak, dewasa ini perlu dikaji secara lebih mendalam. Sebut saja soal pemenuhan kesejahteraan, baik secara rohani maupun jasmani, seperi yang diatur dalam Undangundang No. 4 Tahun 1979. Konsiderans undangundang tersebut mengacu pada pasal 34 UUD 1945, yang mengatakan; fakir miskin dan anak terlar dipelihara oleh Negara. Dalam realisasi kehidupan, hal semacam itu sangat bertolak belakang dengan apa yang tercantum dalam undangundang. Jika saja perlindungan anak benarbenar menjadi perhatian pemerintah, maka apa yang disebutkan dalam Pasal 34 UUD 1945 mengenai fakir miskin dan anak terlantar dipelihara oleh Negara, secara otomatis tentu akan terjamin. Namun, banyak kendala kemudian terjadi dalam aplikasinya. Lihat saja betapa runyamnya masa depan anak dalam pandangan seharihari. Khususnya kota kota besar di Indonesia. Pandangan yang sangat mengusik nurani kemanusiaan. Seperti persoalan ketidak mampuan ekonomi, memang factor dominan yang pada akhirnya menjadikan anak hidup terpaksa dalam keterpaksaan. Semisal mencari rizki dengan cara menjadi pengamen, pedagang asongan, serta berbagai aktivitas anak lainnya yang seharusnya dilakukan oleh orang dewasa. Menjadi gelandangan demi mempertahankan hidup, sangat mungkin lebih baik bagi mereka. Tetapi sebagai tanggung jawab Negara, maka hal ini sangat buruk mengingat mereka sebagai generasi penerus bangsa. Bila persoalan anak tidak menjadi perhatian yang serius, maka bangsa yang besar dengan beraneka ragam semboyan, tentu akan padam. Sebab mengabaikan generasi penerus bangsa sama artinya dengan menghancurkan Negara dan bangsa Indonesia ke depan. Penting memang, perhatiaan tersebut dapat menjadi kesadaran pemerintah. Betapa banyak anakanak terlantar yang seharusnya diperlihara oleh Negara, kini terpaksa tinggal dikolom jembatan dan di trotoar jalan.

Mestinya hak-hak seorang anak tersebut tidak begitu saja dilupakan.
Undang-undang No. 4 Tahun 1979 tentang Kesejahteraan Anak menjadi alasan kuat, mengapa kesejahteraan terhadap anak mejadi prioritas utama yang harus diperhatikan. Misalnya, hak atas perawatan, asuhan, bimbingan serta kasih saying dari oraang tua. Semua hal tersebut menyangkut dengan perkembangan anak yang wajar. Kalaupun anak yang tidak punya orang tua, maka ada ketentuan lain yang mengatur dengan sangat rinci. Padahal kita ketahui bahwa anak yang tidak mempunyai orang tua berhak memperoleh asuhan oleh Negara, atau orang, atau badan lain. Swehingga diharapkan anak dapat tumbuh berkembang secara wajar baik jasmani maupun rohani, tanpa membedakan jenis kelamin, agama, pendidikan, dan kedudukan sosial (Pasal 4 ayat 1 Undangundang No. 4 Tahun 1979).

Pertsoalan yang dihadapi anak di Indonesia saat ini sangat pelik. Lihat saja berbagai kasus yang terjadi di kota besar. Bukan hanya sekedar memprihatinkan. Tetapi juga mempunyai latar belakang dan ketidakmampuan yang sangat luar biasa. Ini juga terjadi dalam berbagai hal, seperti bidang pendidikan, perilaku, agama dan sebagainya. Jika fenomena ini dibiarkan begitu saja, maka dipastikan anak kelak akan menjadi komoditas dalam berbagai bentuk, katakalah komuditas bisnis demi meraup keuntungan. Maka, pengangguran dan keterbelakangan pendidikan kemudian dimanfaatkan untuk kepentingan mendapat uang oleh sekelompok orang demi kepentingan pribadi.

Kota besar menjadi lahan empuk bagi merekayang jelas-jelas memenfaatkan keuntungan tersebut, betapa tidak, lembaga anak sendiri sepertinya kewalahan menangani banyaknya anak yang telah menjadi pengagguran. Realitas ini sepertinya kurang sekali mendapat perhatian dari pemerintah maupun maasyarakat. Sehingga kasus-kasus dikota besar sepertinya sudah terbiasa dengan keadaan seperti itu. Masyarakat pun tidak lagi berfikir, bahwa mereka jaga punya tanggung jawab terhadap apa yang terjadi 
pada anak belakangan ini. Terdapatnya pelbagai kasus yang terjadi di Jakarta dengan memanfaatkan anak untuk menjual berbagai jenis narkoba adalah potret buram bangsa Indonesia maka sudah sepatutnya, kita menilai Undang-undang No. 23 Tahun 2003 tentang Perlindungan Anak haanya tinggal diatas kertas yang sama sekali tidak ada manfaatnya.

Padahal semestinya, yang berkewajiban dan bertanggungjawab terhadap penyelenggaraan dan perlindungan anak adalah Negara dan pemerintah menurut Pasal 20, Undang-undang No. 23 tahun 2002 tentang Perlindungan Anak. Hal tersebut diatur sesuai dengan konvensi Hak Anak Internasional. Kemudian selanjutnya tugas Negara dan pemerintah adalah; memberikan dukungan sarana dan prasarana, seperti sekolah, lapangan bermain, lapangan olahraga, tumah ibadah, gedung kesenian, tempat rekreasi, tempat penitipan anak dan rumah tahana anak (Pasal 22, UU PA).

Peran masyarakat juga sangan membantu dalam memberikan kesejahteraan anak. Bias saja beran ini menyangkut peran individu maupun badan sosial. Seharusnya oranmg tua dan keluarga menjadi pusat pelayanan pemenuhan hak anak, seperti penamaan yang baik dan indah, upacara ritual pengasdzanan, khitam, aqiqah, penafkahan dari harta yang halal dan baik, pemeliharaan lingkungan rumah yang baik, pemeliharaan sekolahayang baik, dan pendampingan minat dan bakat sesuai dengan potensi anak. Semua hak anak tersebut merupakan proses perlindungan hak anak secara syar'i.

Sudah menjadi kewajiban pemerintah untuk memberikan dorongan, bimbingan, konsultasi, dorongan serta baantuan. Hal tersebut merupakan tanggung jawab kolektif dari Pemerintah di bawah koordinasi Kementerian Kesejahteraan (Menko Kesra) dimana setiap lini member perhatian dasar dan mengembangkan program pencerdasan anak Indonesia di setiap sektornya.
Untuk itu tidak ada alas an membiarkan anak dalam kondisi apapun. Karena menurut Pasal 22 dalam UU No. 23 Tahun 2003 tersebut sudah jelas akan tanggung jawab Negara dan pemerinyah dalam hal pemenuhan kebutuhan terhadap anak terlantar dan kurang mampu. Sehingga masalah yang memprihatinkan yang akan menimpa anak Indonesia ke depan bias terselesaikan dengaan baik, dan benar-benar menjadi orang Indonesia yang punya masa depan cerah daan terarah.

\section{Konveksi Hak Aanak PBB}

Pada tangga 20 November tahun 1989 Perserikatan Bangsa-Bangsa telah mengesahkan Konveksi Hak Anak (Child Right Convention). Konvensi ini paling banyak ditandatangani oleh Negara-negara. Bahkan Indonesia sendiri telah meratifikasi konvensi tersebut dengan keputusan Presiden Nomor 36 Tahun 1990. Retifikasi tersebut berdasarkan Hukum internasional dalam dua bentuk.

Pertama, proses ratifikasi tersebut dimintakan persetujuan Dewan Perwakilan Rakyat (DPR) selaku wakil rakyat, karena hukum anak yang akan diratifikasi tersebut akan mengikat seluruh rakyat Indonesia. Sehingga menjadi kewajiban warga Negara untuk setiap saat melindungi dan menjaga tanggung jawab atas apa yang telah diraativikasi tersebut.

Kedua, proskeputusan Presiden dalam pengertian tidak meminta persetujuan DPR jika meratifikasi hak-hak anak itu, tetapi Presiden hanya memberitahukan saja kepada Dewan Perwakilan Rakyat (DPR) apa yang telah diratifikasi, khususnya mengenai hak-hak anak. Tetapi ini juga masih menjadi pro dan kontra di kalangan praktisi hukum. Sementara bagi kelompok yang pro tentu punya alasan sendiri, mengingat tuntutan perkembangan zaman yang semakin cepat. Jika harus meminta izin DPR, maka prosedur yang belit-belit itu dikhawatirkan dapat menjadikan bangsa dan Negara Indonesia akan tertinggal. Sementara, pihak yang kontra mengacu pada retifikasi Hukum Internasional harus 
dalam bentuk undang-undang. Karena ada abanyak kendala yang memungkinkan tidak sesuai budaya Indonesia. Sehingga retifikasi tersebut akan mengikat secara hukum dan harus dipatuhi oleh masyarakat Indonesia. Kalau Hukum Internasional yang diadopsi, maka akan sangat memungkinkan Hukum Nasional menjadi perubahan pada budaya masyarakat Indonesia.

Kendati hal tersebut terjadi pra dan kontra mengenai retifikasi Hukum Internasional tersebut, namun secara otomatis menimbulkan kewajiban bagi setiap warga Negara (tanpa terkecuali) untuk menjamin perlindungan terhadap hakhaka anak. Sekaligus merupakan Hak Azasi Manusia (HAM) yang perlu dilindungi oleh hukum. Bahkan perlindungan sejak dalam kandungan sekalipun. Dalam mewujudkan perlindungan Negara terhadap anak, konvensi Hak Anak Internasional mewajibkan Negara untuk melakukan pencegahan agar anak dapat terhindar dari penculikan, penyelundupan, serta penjualan. Bahkan, perlindungan itu juga termasuk pekerjaan yang dapat mengancam kesehatan, pendidikan dan perkembangannya. Termasuk juga soal penyalagunaan obat bius dan narkotika. Melindungi dari faktor eksploitasi, penganiayaan seksual, prostitusi, keterlibatan dalam pornografi serta berbagai bentuk diskriminasi.

Perlindungan itu juga mengarah kepada perlindungan anak yang menjadi korban konflik, seperti yang pernah terjadi di Aceh, Ambon, dan Poso. Karena wilayah yang terlibat berbagai peristiwa konflik bersenjata atau peperangan membuat anak rentan menjadi korban. Katakana dalam hal pengunsian. Kondisi ini memungkinkan anak sama sekali tidak mendapat haknya sebagai warga Negara dan perlindungan hukum yang maksimal, seperti yang telah diatur dalam berbagai bentuk undangundang.

\section{KESIMPULAN}

Dari beragam penjelasan sebagaimana di atas, pada prinsipya dari sisi kehidupan beragama, berbangsa dan bernegara, anak merupakan amanah, masa depan dan asset bangsa sekaligus generasi pelestari cita-cita agama dan bangsa, sehingga tiaap anak berhak atas kelangsungan hidup, tumbuh dan berkembang, berpsrtisipasi serta berhak atas perlindungan dari segala tindak kekerasan dan diskriminasi, karena memiliki hak sipil dab hak kebebasan. Adapun yang bertanggung jawab untuk menjaga dan memelihara hak asasi tersebut adalah para orang tua, keluarga, masyarakat, pemerintah dan Negara. Perlindungan anak ditujukan untuk merealisasikan kehidupan terbaik baagi anak yang nota bene sebagai generasi bangsa secara penuh potensi, tangguh dan terhadap bangsa dan Negara.

Adapun terkait dengan masalah penegakan hukum perlindungan anak, bukan terletak pada aturan main, akan tetapi terletak pada aturan main, akan tetapi terletak pada hilangnya etika dan hati nurani pada penegak hukum -hakim dan jaksa yang beragam, tidak seiring dan sejalan dalam persepsi mengenai penetapan hukuman bagi terdakwa guna melindungi anak. Terlebih lagi, dalam pelaksanaan sistem peradilan pidana anak terutama menyangkut dengan teknis persidangan, masih ada mispersepsi dalam tata cara persidangannya, padahal sudah jelas bahwa tata cara peradilan pidana anak harus mengedepankan tidak adanya kesan yang menyeramkan, semisal para Hakim dan panitera peradilan tidak diperkenankan memakai seragam pengadilan (toga) agar bertujuan mengesankan bahwa dalam teknis peradilan anak, nuansa dan kondisinya lebih bersifat semi formil (relax) yang sudah tentu sangat berbeda dengan teknis dan tata cara peradilan pidana umum, serta Hakim pengadilan anak harus memiliki nilai moral dan empati yang tinggi terhadap anak yang sedang diadilinya, karena pengadilan anak lebih mendahulukan kepentingan terbaik bagi seorang anak seperti apa yang diamanatkan oleh Undang-undang No. 23 tahun 2002 tentang perlindungan Anak. Kemudian kepastian hukum dan kelancaran 
persidangan tidak dapat mengalahkan prinsip perlindungan hak tersangka (anak).

Anak harus dibesarkan dari segala ketidakmampuan dan kegagalan manajemen system peradilan pidana, selama belum ada tahanan untuk anak maka alasan penangkapan dan penahanan yang diatur dalam KUHP (UU No. 8 tahun 1981) harus dukesampingkan. Kepastian hukum dan kelancaran peradilan anak hanya dapat terlaksana dengan membangun sistem peradilan pidana anak. Oleh karena itu, MA sebagai pemegang kekuasaan kehakiman harus segera merealisasikan sistem peradilan pidana yang kondusif bagi anak di Indonesia. Artinya, pada saat mendatang diharapkan tidak terjadi lagi pengulangan kesalahan teknis peradilan pidana anak seperti yang terjadi pada kasus Mohammad Azwar yang akrab dipanggil Raju beberapa waktu yang lalu. Sesungguhnya perlakuan terhadap anak merupakan masalah kognitif (cara berfiki), perilaku (terbentuknya kebiasaan untuk bereaksi terhadap perilaku anak), dan sosial cultural (adanya keyakinan dan praktik-praktik yang memperoleh legitimasi dan restu masyarakat). Perlindungan terhadap anak merupakan fenomena sosial yang memerlukan perhatian kita semua, sudah saatnya berbagai komponen bangsa ikut serta dalam mempersiapkan anak-anak menjadi generasi yang berkualitas yang memiliki kompetensi dan kemampuan kompetensi dalam persaingan global. Lingkungan yang aman harus diciptakan demi tumbuh kembangnya kepribadian anak secara maksimal. Sehat jasmani, mental, emosional, intelektual dan spiritual. Sehingga anak Indonesia dapat memperoleh jaminan untuk memperoleh aksesbilitas layanan kesekatan, pendidikan, kelangsungan hidup, tumbuh kembang serta hak parsitipasi baik secara fisik maupun psikis.

\section{DAFTAR PUSTAAKA}

Barker, Chris. Dialih bahasakan oleh Nurhadi. Cultural Studies, Teori dan Praktek. Yogyakarta: Kreasi Wacana, 2000.

Gosita, Masalah Perlindungan Anak: Akademik Prasindo, 1985.

Gosita, Masalah Korban Kejahatan: Akademik Prasindo, 1985.

Hendarto. Relevansi Viktimiologi Dengan Pelayanan Terhadap Korban Perkosaan. Jakarta: Lintas Buana 1999.

Himawan, Charles. Hukum Sebagai Panglima. Jakarta:Kompas 2000.

Charliyan, Anton. Penanganan Kekerasan Seksual Pada Anak, 2006.

Soekanto, Soerjono. (Ed), Pokok-Pokok Sosiologi Hukum. Jakarta: Raja Grafindo Persada, 1997.

Undang-Undang Dasar 1945 Republik Indonesia.

Undang-Undang Republik Indonesia Nomor 23 Tahun 2002 tentang Perlindungan Anak.

Undang-Undang Republik Indonesia No. 4 Tahun 1979 tentang Kesejahteraan Anak.

End Child Poverty Newspaper. www. Kompas.co.id. www. Smeru.or.id www. Tempo Interaktif.com www. Komnaspa.go.id 